\title{
The New York Times: уникальный опыт семейного бизнеса
}

Арина Новгородова

В статье обозначены основные периоды становления и развития газеты The New York Times, рассматриваются особенности менеджмента газеты, эволюция принципов редакционной политики издателей газеты (семейство Окс - Сульцбергеров), деятельность The New York Times в условиях кризиса.

Ключевые слова: качественная газета, The New York Times, Окс, Сульцбергер, США. (c) Новгородова Арина Игоревна соискатель кафедры теории и экономики СМИ факультета журналистики МГУ имени М.В. Ломоносова (г. Москва, Россия), arin_83@mail.ru

\section{Введение}

Появление в Соединенных Штатах Америки, молодом независимом государстве, железных дорог и телеграфа в первой половине XIX в., повсеместно за короткий срок значительно ускорило передачу и распространение информации. Общий годовой тираж всех газет с 1828 по 1840 г. вырос более, чем в два раза (с 68 млн до 148 млн экз.) (Schiller, 1981: 12). Исследователи полагают, что это было связано с более высоким уровнем грамотности аудитории и увеличением свободного времени (Schudson, 1978: 15-17; Вартанова, 2003: 112-123). В аудитории с невысоким доходом были заинтересованы и рекламодатели, что, с одной стороны, позволило снизить цену газеты, а с другой - сделать ее не только окупаемой, но и прибыльной. Уже в 1820-1830 гг. появилось много изданий, предназначенных для конкретной аудитории: работающих мужчин, коренных американцев и иммигрантов, свободных чернокожих, женщин, а также представителей различных религиозных конфессий. Такие недорогие ежедневные газеты за один цент, ориентированные на развлечение своих читателей, были дешевле, чем коммерческие и политические газеты (Михайлов, 2004). Так в противовес качественной появилась массовая пресса. Классическое деление 
прессы по типологическим характеристикам на качественную и массовую возникло в 30-х гг. XIX в., когда в США и Европе стали выходить в свет ежедневные газеты, предназначенные для нового читателя с невысоким уровнем дохода и минимальным образованием. Первую массовую газету в Соединенных Штатах Америки - The New York Sun - основал в 1833 г. Бенджамин Генри Дей. Четырехполосная газета стоимостью один цент выходила два раза в день и имела немыслимый для того времени тираж - 30 тыс. экз. В 1820 г. в США выходило 24 ежедневные газеты, что было мировым рекордом. Главная особенность американской массовой прессы заключалась в том, что в погоне за сенсацией газеты стремились не просвещать читателя, а заработать как можно больше денег (Прутцков, 2010: 90-98).

Однако по мере развития рыночных отношений в политических и деловых кругах возникла потребность в создании влиятельного органа прессы для высокообразованной аудитории, который бы не только освещал вопросы экономики, но и предоставлял читателю полную и объективную информацию о внутренней и внешней политике, общественной и культурной жизни (Беспалова, Корнилов, Короченский, Лучинский и др., 2003: 34). Такой стала качественная газета The New York Times.

\section{0бзор литературы}

По мнению исследователей, американская модель СМИ после второй мировой войны во многом определила пути трансформации мировых медиа (Макеенко, 2003:9) и знание особенностей развития американских СМИ на разных исторических этапах позволяет лучше разобраться в механизмах функционирования современного рынка прессы Соединенных Штатов.

Опубликованные в советский период отечественные исследования основное внимание уделяли изучению публикаций
The New York Times об отдельных политических, военных событиях, которые имели широкий резонанс. Так В.М. Кондратенко (1979) посвятила диссертационную работу вопросу эволюции редакционной политики газеты в освещении политического курса США во вьетнамской и ближневосточной войнах, а также в отношении разрядки международной напряженности, И.В. Рогозина (1988) - пропагандистскому методу воздействия политических текстов газеты. Российскими учеными (Засурский (ред.), 2015; Вартанова, 2003; Михайлов, 2004; Калягин, 2012; Маркина, 2004; Макеенко, 2003 и др.) подробно изучена история становления качественных изданий США и их специфика.

В англоязычной литературе о The New York Times превалируют работы, написанные либо ее руководителями и сотрудниками, либо авторами, прошедшими редакционную школу The New York Times. Так, М. Бергер - один из лучших репортеров газеты - к 100-летнему юбилею издания выпустил в 1952 г. книгу «История The New York Times. 1851-1951 гг." (The Story of The New York Times. 1851-1951). Г. Тализ (1969) - автор материалов по расследовательской журналистике, многие годы проработавший в The New York Times, - представил неофициальную историю газеты 1950-1960 гг. в монографии «Королевство и власть» (The Kingdom and the Power). Безусловно, ценный источник по истории газеты - труды таких известных журналистов, как Г. Солсбери (1980) и Р.Ф. Шепард (1996). В 1971 г. были опубликованы мемуары Т. Кэтлиджа (1971) - главного редактора The New York Times в 1950-1960 гг., а в 1981 г. (первое издание для друзей и семьи было издано в 1979 г.) вышла книга «Ифигения» (Iphigene), в которой внучка Адольфа Окса Ифигения Сульцбергер рассказывает о своем непосредственном участии в развитии газеты. Однако, ввиду личной вовлеченности данных авторов в описываемые ими события 
и процессы развития The New York Times, эта литература потребовала критического анализа и переосмысления. Отдельного внимания заслуживают труды критиков прессы США, в первую очередь классическая работа А. Синклера (1921), монография Э. Даймонда (1994), с богатым фактическим материалом и содержательным анализом различных аспектов функционирования газеты (типология, история, взаимоотношения институтов государства и средств массовой информации, этические проблемы, отдельные медиа и т.д.).

Итак, потребность в дальнейшем изучении эталона качественной мировой прессы сохраняется. Актуальность нашего исследования связана с изучением функционирования The New York Times на современном этапе, с тем, как одна из самых авторитетных и старейших качественных газет США справляется с новыми вызовами XXI в., какие шаги предпринимает для сохранения традиций и дальнейшего развития.

\section{The New York Times: становление}

Первый выпуск газеты The New York Times (с момента основания до 1857 г. - The New York Daily Times) вышел в свет 18 сентября 1851 г. Газету, в противовес существующим массовым изданиям, основал политик и журналист Генри Раймонд совместно с банкиром Джорджем Джонсом (на запуск газеты было затрачено 70 тыс. долл. США). С самого начала газета ориентировалась на серьезные журналистские материалы, отказавшись от сенсационных публикаций. Это было заявлено уже в первый день выхода газеты: «...мы не намерены писать так, словно находимся в порыве гнева [выпад в адрес Хораса Грили, журналиста и политического деятеля, который был постоянным предметом насмешек детища Г. Раймонда. - А.Н.], за исключением действительно веских случаев, и мы будем впадать в ярость настолько редко, насколько это возможно» (Emery, 1988: 129).
Одним из направлений информационной политики The New York Times было комментирование зарубежных новостей. Г. Раймонд стремился усовершенствовать подачу новостей из Европы. «В политических и социальных вопросах The New York Times будет консервативной, это лучший способ помочь реформам», - считал он. Отметим, что к моменту создания New York Times традиции американской печати уже устоялись, и американцы относились с большим доверием к печатному слову и к газете как источнику получения информации из внешнего мира и главному ориентиру в повседневной жизни (Засурский (ред.), 2015: 156).

Г. Раймонд был не только одним из лучших журналистов XIX в, но и талантливым редактором, имевшим влияние в республиканских кругах. Через два года после основания The New York Times в пределах города продавалась лучше, чем The New York Tribune, выходившая с 1841 г. Заслуга Раймонда заключается также в том, что он внедрил правила хорошего тона в процесс информирования общества - недопустимы были любые оскорбления личного характера. Интересно, что в штате газеты были корреспонденты-детективы, которые способствовали росту влияния газеты, проводя действительно серьезные расследования: в частности, в 1870-1871 гг. они помогли раскрыть махинации могущественной организации мафиозного типа «ТамманиХолл» (Tammany Hall). Это был звездный час The New York Times.

Однако к 1896 г. тираж газеты упал до 9 тыс. экз., долг вырос до 300 тыс. долл., от нее отвернулись читатели и рекламодатели. Серьезному изданию было сложно противостоять развлекательной прессе, ориентированной на читателя, интересующегося только скандальными и сенсационными публикациями.

Новая страница в истории The New York Times связана с именем Адольфа Окса. Его 
деловая хватка и лидерские качества позволили весьма эффективно управлять газетным бизнесом. Он получил хорошую практику в газете The Chattanooga Times, которая, в том числе благодаря его усилиям, успешно развивалась, и к 1892 г. имела ежегодно 25 тыс. долл. чистой прибыли. У Окса не было денег, чтобы спасти The New York Times, но у него было ясное представление о том, как сделать газету конкурентоспособной. Выработанный А. Оксом план рефинансирования был перспективным и обеспечивал ему контроль над газетой на четыре года в случае ее успешного обновления. Окс в течение многих месяцев посещал район Уолл-стрит, предлагая богатым финансистам купить облигации нового предприятия, доказывая, что это выгодные инвестиции. Опираясь на то, что New York Times приобрела репутацию объективной и независимой газеты, Окс обратился к читателям с «деловым заявлением», которое позже сама The New York Times назвала «Декларацией принципов». Заявление, за подписью Адольфа Окса, было опубликовано на первой полосе газеты 19 августа 1896 г.

Первые шаги А. Окса были простыми, но эффективными. Так, газета стала публиковать путеводитель по городу для покупателей, приезжавших в Нью-Йорк, ежедневно сообщала об операциях с недвижимостью, добавила к ежедневному обзору новости с торговых бирж и еженедельное финансовое обозрение, а юристам предлагала информацию об отчете с судебных заседаний. Аудитории, на которую рассчитывал Окс, также нравилось особое выделение новостей о деятельности правительства. Финансовые и деловые круги находили статьи The New York Times все более ценными.

Адольф Окс сформулировал девиз газеты - «Все новости, достойные печати» (All the News That's Fit to Print)1. По его замыслу издание должно было стать своего рода энциклопедией новостей, предоставляя солидному читателю только объективную информацию «без страха и предпочтений» (without fear and favor). The New York Times публикует материалы, фактическая сторона которых сомнений не вызывает. Это единственная газета, которая печатает полные тексты законопроектов и пресс-конференций президента, отчеты о бюджете правительства, послания Папы Римского, наиболее значительные документы, заявления, речи и выступления европейских руководителей, американских сенаторов и конгрессменов, глав крупнейших международных общественных организаций (Кондратенко, 1979). Одним из фундаментальных принципов издания становится четкое разделение новостей и их комментирование (Беспалова, Корнилов, Короченский, Лучинский и др., 2003).

Благодаря Оксу в газете появились две новые рубрики: Book Review («Книжное обозрение») и The New York Times Magazine c аналитическими статьями. Но главной заслугой А. Окса в редакционной политике газеты стало приоритетное внимание к международным новостям. The New York Times буквально открыла своим читателям «окно в мир». Окс вкладывал огромные деньги в оборудование, строил новые типографии, расширял штат. Адольф Окс умер в 1935 г., но именно благодаря его усилиям в 1936 г. ежедневный тираж The New York Times coставил 400 тыс. экземпляров, а прибыль от рекламы - около 100 млн долл. (см. табл.).

Журналистскую практику газеты изменило изобретение в 1880 гг. телефона - появилась возможность оперативно публиковать информацию о событиях не только в НьюЙорке, но и в соседних городах. В начале XX в. The New York Times более глубоко и всесторонне освещает и внутренние, и международные события. Корпункты газеты открывались не только в американских городах, но и во многих странах мира. Четкость и оперативность работы редакции заслуживает освещение гибели «Титаника» 15 апреля 1912 г. Сообщение, полученное 
Таблица. Ежедневный тираж The New York Times, 1896-1936, тыс. экз.

\begin{tabular}{|l|c|c|c|c|c|c|}
\hline Год & 1896 & 1898 & 1905 & 1910 & 1922 & 1936 \\
\hline Тираж & 19 & 25 & 82 & 192 & 343 & 400 \\
\hline
\end{tabular}

Источник: Schudson, 1978: 114-119.

The New York Times в 1 ч. 20 мин., уже через два часа было опубликовано со всеми подробностями, полным списком жертв, фотографией «Титаника» и его капитана.

Постепенно The New York Times превращалась в авторитетное и влиятельное издание. По мнению журналиста Уилла Ирвина, она «ближе всех других газет подошла к объективному и правдивому отражению жизни Нью-Йорка и мировых событий в целом» (Засурский (ред.), 2015: 165).

\section{Семейная корпорация Окс - Сульцбергеров}

Преемники Адольфа Окса стремились придерживаться его принципа: газета должна оставаться «полностью независимым печатным органом, абсолютно бесстрашным, преданным исключительно интересам и благосостоянию нации, без оглядки на собственные привилегии, амбиции и выгоду, не подчиняющимся никаким политическим партиям и группировкам, а также личным предубеждениям и пристрастиям» и впредь отражать «самые передовые взгляды и мнения», «проводить политику объективной подачи информации»².

Сегодня управление редакцией The New York Times построено таким образом, чтобы обеспечить информационную деятельность издания путем укрепления его экономической, финансовой базы, способствовать воспитанию экономического мышления у сотрудников редакции. С этой целью была создана служба менеджмента, во главе с президентом и генеральным директором, которая отвечает за все коммерческие операции газеты, включая рекламу, тираж, маркетинг, производство, кадры, финансы, стратегическое планирование, трудовые отношения и работу информационных служб газеты. Творческие процессы в The New York Times также находятся под контролем корпоративного менеджмента, способствующим усилению экономических акцентов, стандартизации контента, оказывающим жесткое финансовое давление на журналистов, что, к сожалению, приводит к развитию так называемых «сервисных» функций в газете, сужению круга серьезных тем и появлению скандалов, связанных с нарушением этических норм газетной отрасли.

Как отмечают исследователи, «структура средств массовой информации в обществе обусловливается сложным комплексом социально-политических, экономических, юридических... и научно-технических факторов. Историческое развитие всех этих факторов в их взаимодействии привело к формированию в качестве структурной единицы <...> крупных монополистических объединений, сосредоточивших в своих руках подавляющую часть издательской и радиотелевизионной индустрии (Андрунас, 1991: 3). Ярким примером такой крупной акционерной компании, где доминирует семейный контроль, является глобальная медиакорпорация The New York Times Company (зарегистрирована 26 августа 1896 г.) - одна из лидирующих в данном секторе. Кроме The New York Times она владеет ежедневной газетой The Boston Globe, региональными газетами, журналами, телеи радиостанциями, долями в типографиях ${ }^{3}$ и т.п., подтверждая в очередной раз, что «наиболее прибыльной, гибкой формой организации СМИ являются многоотраслевые корпорации» (Ахмадулин, 2001). The New York Times, претендующая с конца XIX в. на статус ведущего национального средства массовой информации, демонстрирует свою уникальность, оставаясь семейным бизнесом. Для Оксов - Сульцбергеров качество по-прежнему важнее прибыли. 
Не удивительно, что жители Нью-Йорка считают свою газету лучшей в мире, ведь главные ее достоинства - стабильность (неизменны даже формат и шрифт) и авторитет. Новости, попавшие на первую полосу The New York Times, - самые важные в мире.

\section{Артур Хейс Сульцбергер (издатель The New York Times в 1935-1961 гr.)}

После смерти Адольфа Окса The New York Times переходит к его зятю Артуру Хейсу Сульцбергеру и племяннику Джулиусу Оксу Адлеру. А.Х. Сульцбергер руководил газетой более четверти века, отличительной чертой газеты при А.Х. Сульцбергере стали аналитические обзоры и высококвалифицированные комментарии важнейших событий внутренней и международной жизни, что способствовало привлечению читателей (из среды деловых кругов, интеллигенции), а следовательно, и росту тиража.

Репутация The New York Times как одной из ведущих газет Соединенных Штатов Америки еще более упрочилась. В то время, когда средний объем ежедневной нью-йоркской газеты составлял 42 полосы, в The New York Times было 90 полос. В типографии The New York Times насчитывалось 1800 рабочих, в редакции - 616 сотрудников, в конторе - 953, в правлении - 84 (Кугель, 1931).

Издание вовремя отреагировало на появление радио - так, уже в 1922 г. в газете появляется специальная рубрика Radio Section, с анализом радиопередач, анонсом программ ведущих радиокомпаний, а также рекомендациями радиолюбителям. Особым объектом обсуждения стало политическое радиовещание, газета подчеркивала важную роль радиовыступлений Президента Ф.Д. Рузвельта: «Использование этого нового инструмента политических дискуссий является откровенным намеком конгрессу на то, что президент может обратиться к этому средству, если возникнет необходимость в поддержке законопроекта, который он вносит, но который законодатели не расположены утверждать» (Berger, 1952: 2).

\section{A.0. (Панч) Сульцбергер (издатель The New York Times в 1961-1990 гr.)}

Большой вклад в развитие The New York Times внес A.O. (Панч) Сульцбергер. Именно в это время The New York Times (одна из первых в мире) стала использовать новые информационные технологии (факсимильную печать и спутниковую связь), которые в 1960-1970-х гг. были разработаны для воинских частей. Наиболее важным для The New York Times оказалось внедрение ЭВМ в сферу активного хранения газетного материала. Создание автоматизированного архива в New York Times положило начало широкому влиянию ЭВМ в деятельность редакции и всей компании (Вартанова, 1988: 74).

Новый издатель стал известен после публикации секретных материалов Пентагона (Pentagon Papers) о действии администрации Президента Ричарда Никсона во время войны во Вьетнаме. Белый дом под угрозой закрытия газеты обратился с требованием остановить публикацию в целях соблюдения государственной безопасности. Но серия статей вышла в свет, а Верховный суд принял решение в пользу The New York Times. Корреспондент Г. Солсбери расценил дело о документах Пентагона не только как большую конфронтацию между печатью и администрацией Никсона, но и как превращение The New York Times в новый социальный институт, в подлинно четвертую власть. По его словам, эта газета вместе с The Washington Post глубоко изменила саму журналистику (Salisbury, 1980).За эту серию публикаций газета получила Пулитцеровскую премию. Отметим, что The New York Times или работавшие в ней журналисты 31 раз становились лауреатами Пулитцеровской премии. Большой вклад в развитие 
газеты внесли А. Розенталь (ответственный секретарь), редакторы различных выпусков Т. Бернштейн, Р. Коэн, Э. Фридман и др.

В 1976-1978 гг. в The New York Times произошли изменения в тематическом содержании публикаций. Редакторы попрежнему уделяли основное внимание статьям по социальной и экономической проблематике. Поддержку со стороны читателей получило решение заполнить газетные полосы статьями о моде, архитектуре домов и дизайне квартир. Статьи о новых ресторанах и супермаркетах напрямую были связаны с рекламодателями. В газете появляются четыре дополнительные рубрики: «Спорт», «Дом и быт», «Искусство», «Уикэнд», рассчитанные на молодых читателей, проводящих большую часть времени перед телевизором. Тогда же выходит в свет самостоятельное приложение «Деловой день», которое предлагает широкое освещение финансовых и экономических вопросов.

Осознав, что одним из важнейших факторов привлечения новых рекламодателей является распространение газеты, отдел по продаже рекламы в начале 1970 гг. начал компанию по увеличению количества регионов, выписывающих газету. Доставка на дом исключала ненадежность продажи газеты в киосках, а постоянная подписка обеспечивала предсказуемость ежедневного распространения без наценок посредников. Теперь рекламодатели любого отдаленного округа были уверены, что их объявления достигнут желаемой аудитории. Таким способом газета подтверждала свое стремление стать общенациональной газетой.

За время правления А.О. Сульцбергера расширилась география распространения The New York Times. В 1980 гг. газета вкладывает 100 млн долл. в издание, выходящее в Калифорнии. The New York Times выписывали в штатах Коннектикут, Нью-Джерси, Лонг-Айленд, Мичиган, Иллинойс, Пенсильвания, Колумбия, Массачусетс. Пробные выпуски издания представляли собой отредактированные новости и статьи ньюйоркского издания и имели большой успех.

В 1989-1991 гг. Соединенные Штаты Америки охватил сильнейший за послевоенные годы экономический кризис, что привело к катастрофическому уменьшению объема рекламы в газетах и журналах. Газетная индустрия США испытывала также определенные трудности, связанные с падением интереса американцев к чтению серьезных газет. «Неуклонно сокращалось общее число ежедневных газет. В 1991 г. более десяти вечерних изданий либо закрылись, либо слились с другими, либо перешли на утренний выпуск. Прекратили существование газеты с долгой историей, начавшие издаваться еще в XIX в. Среди основных причин закрытия - экономический спад и проблемы распространения» (Голованова, 1996: 35).

СМИ США претерпели серьезные изменения с начала 1990 гг., а именно со времени войны в Персидском заливе 1991 г., когда отчетливо проявилось преимущество телевидения. В 1991 г. существовала только одна американская кабельная сеть - CNN (24-часовой канал новостей, который основал в 1980 г. предприниматель Тэд Тернер). CNN выделилась из числа других медиакомпаний, предоставляя своей аудитории оперативное освещение хода войны в Персидском заливе - впервые в истории с места событий прямо на телеэкраны всего мира. Обозревателями был предложен термин «эффект CNN», обозначающий воздействие оперативных, освещаемых в режиме реального времени общественных и политических новостей. Большинство американцев получало информацию о событиях в мире благодаря местным и национальным телевизионным новостным каналам, радио, местным и центральным газетам.

Огромное влияние на СМИ, безусловно, оказал Интернет. Семейство Окс - Сульцбергеров быстро сориентировалось в новой 
реальности - The New York Times одной из первых начала распространять новости во Всемирной сети. А к началу XXI в. почти все традиционные СМИ стали размещать новости на собственных веб-сайтах, в которых часто комбинировалась видео-, аудио- и печатная информация. В то же время специализированные сайты и блоги стали представлять серьезную конкуренцию традиционным СМИ.

\section{Артур Окс Сульцбергер-младший (издатель The New York Times в 1992-2017 гr.)}

В 1990 гг. The New York Times переходит из качественного в смешанный тип издания. Новое поколение читателей требовало более легкого стиля статей, и, чтобы спасти газету, Артуру Оксу Сульцбергеру-мл. пришлось пойти на уступки. «Мы должны потратить все наши усилия и вложить средства на развитие другого бизнеса, из которого можно извлечь значительные прибыли, - заявил новый издатель на собрании акционеров в мае 1992 г. - В результате экономического кризиса мы не можем продолжать уделять внимание только изданию печатной версии нашей главной газеты. Будущее... за электронными массмедиа, и мы должны идти в ногу со временем» (Diamond, 1994: 372).

При А.Оксе Сульцбергере-мл. изменился и облик The New York Times. C 1993 г. в воскресных приложениях появились цветные фотографии. Как подметил журнал Newsweek, «"Седая леди [так называли The New York Times. - A.H.] румянится и красит губы" (а "седой леди" - 146 лет)» (цит. по: Засурский (ред.), 2015: 172). С «Седой леди» читатели окончательно простились 16 октября 1997 г., когда газета вышла с цветом на легендарной первой полосе.

Новая реальность открыла перед The New York Times новые возможности. Tеперь издание представляло новости как в печатном, так и в цифровом виде, понимая преимущество электронных версий, которое «состоит в способе их передачи и доставки, которыми пользуется часть читателей как единственным источником информации, и в скорости ее получения, не сравнимой страдиционными формами» (Акопов, 1999: 34).

В мае 1994 г. газета открыла сетевую информационную службу @times (на базе крупнейшего интернет-провайдера America Online), а через полтора года запустила сайт The New York Times on the Web (www.nytimes. com). Постоянные читатели газеты - прави тельственные чиновники, крупные бизнесмены, официальные лица из разных стран, которым важно знать именно мнение New York Times по конкретному вопросу. Однако эта аудитория немногочисленна. И чтобы привлечь читателей, в первую очередь зарубежных, в июле 1998 г. руководство газеты The New York Times отказалось от взимания денег с зарубежных посетителей своего сайта. Бесплатный доступ к электронной версии The New York Times имели только американцы, а иностранцы должны были платить 35 долл. в месяц или 500 долл. в год. Не удивительно, что у электронной версии газеты было около 4 млн местных подписчиков, в то время как постоянные иностранные читатели исчислялись только тысячами, т.к. большинство из них не видело крайней необходимости платить за электронную версию газеты. (Для сравнения: усредненный размер «бумажного» тиража в 1997 г. составлял 1,9 млн экз., а воскресного выпуска - 1,652 млн экз.) Решение перейти на бесплатную регистрацию оправдало себя - в первый же месяц количество иностранных пользователей nytimes.com превысило количество пользователей, обращавшихся к платной версии в течение двух с половиной месяцев.

Однако далеко не все медиакомпании решали отказаться от подписки на электронные версии периодических изданий. Напротив, многие газеты в 2003 г. перевели свои сайты на платную подписку, провозгласив 
конец эпохе бесплатного Интернета. Так, на модель полной оплаты перешла испанская газета El Pais - 80 евро в год или 50 евро за полгода, создав новую структуру и дизайн сайта. Японская Asahi Shimbun создала службу рассылки новостей для сотовыхтелефонов. за 80 центов в месяц.

С июня 1998 г. на страничке NYToday размещается информация о жизни Нью-Йорка - крупнейшего города США (искусство и развлечение, цены и уровень обслуживания в различных отелях, местные события, карта города и его окрестностей, справочники и многое другое). Общественные издательские центры и издательские клубы получают возможность присылать свои репортажи. Печатное и электронное приложение «Рынок работы» (Job Market) предлагаетуслуги поиска работы в мегаполисе. Приложение выходит в каждом воскресном выпуске The New York Times и доступно в течение недели на сайте nytimes.com (отметим, что данное приложение не отражает мнения и взгляды редакторов и журналистов газеты). В сентябре 1998 г. газета запустила сайт The New York Times Learning Network (более миллиона пользователей в месяц).

Кроме ежедневной электронной версии nytimes.com предлагает воспользоваться газетным архивом. Правда, бесплатно полный текст интересующей вас статьи предоставляют только за прошедшие семь дней (хотя, к примеру, в Российской государственной библиотеке с архивом газеты The New York Times можно ознакомиться бесплатно). Конечно, данный способ приносит хорошие дивиденды. Еще одна платная услуга - кроссворды (в настоящее время 35-40 подписчиков покупают разнообразные кроссворды за 19,95 долл. в год). В ноябре 2001 г. The New York Times представила в Сети новую платную продукцию - коллекцию архивных статей самых известных обозревателей газеты (У. Сэфайр, Т. Фридман, М. Гордона и др.). В дополнение к основным новостным сайтам и мобильным приложениям, компания создала ряд сайтов и мобильных приложений, адаптированные к различным интересам, включая NYT Cooking и Crossword. Газета имеет собственную крупную платформу для блогов журналистов, систему аудиоподкастов (The New York Times Radio) и видеоподкастов (24 подраздела - политика, искусство, спорт, здоровье и пр.), разворачивающих новости в иных плоскостях и делающих газету подлинно современной.

Несмотря на все усилия владельцев финансово-экономический кризис 2008-2009 гг. и стремительное развитие цифровых технологий привели третью по величине медиакомпанию США The New York Times Company и респектабельную The New York Times к сокращению штата сотрудников, урезанию зарплат, изменению формата и дизайна газеты, закрытию малоприбыльных проектов.

Финансовые трудности The New York Times стала испытывать уже с 2005 г. Чтобы решить финансовые проблемы, The New York Times Company занялась поиском новых инвесторов. В сентябре 2008 г. Карлос Слим, один из самых богатых людей мира, приобрел 6,4 \% доли The New York Times Company в собственность за 120 млн долл., став третьим крупным владельцем медиакомпании. Чтобы погасить кредиты в декабре 2008 г. The New York Times Company заявила, что собирается заимствовать 225 млн долл. от продажи 19 этажей нового 52-этажного небоскреба в Манхеттене, в котором она владеет 58\% общей площади (The New York Times Company получит право выкупить обратно свою часть здания, покрыв заем (уже 250 млн долл.) за десять лет, выплатив ренту с процентами).

В конце марта 2009 г. издательский дом The New York Times объявил о сокращении заработной платы своим сотрудникам на 5\% на срок до девяти месяцев, а также о предстоящем увольнении еще 100 человек. Сокращения затронули в основном рабочих, не являющихся членами профсоюза 
работников СМИ. Причиной предпринятых мер называли все тот же финансовый кризис и сокращение в связи с этим рекламы в изданиях компании. После объявления о предстоящем сокращении сотрудников акции The New York Times подорожали 26 марта 2009 г. на 23 цента (5,03\%) - до 4,8 долл. за одну ценную бумагу4. Главный редактор издания Билл Келлер пояснил, что сокращение производилось за счет упразднения вакансий, а также путем продажи акций сотрудникам, освобождающим рабочие места. В сложившейся ситуации самым трудным было расставить приоритеты таким образом, чтобы сокращение не затронуло те сферы, в которых газета оставалась наиболее конкурентоспособной. Руководство The New York Times рассматривало также вопрос продажи неэффективных активов издания. 2009 год стал для газеты самым сложным за всю ее историю: кредитный рейтинг управляющей компании The New York Times, которая занимается делами газеты, был снижен экспертами до уровня «ниже инвестиционного»; The New York Times Company заморозила и ряд новых проектов, сократила зарплаты и штат сотрудников, чтобы погасить 400 млн долл. по кредиту. В 2010 г. The New York Times Company нужно было погасить облигации на 250 млн долл., в 2011 г. - еще один кредит в 400 млн долл.

В связи с кризисом по решению руководства The New York Times с 2011 г. стала взиматься плата с потребителей за предоставляемый контент на основных новостных сайтах и мобильных приложениях газеты (цифровые подписки можно приобрести индивидуально или корпоративно). К определенному количеству статей в месяц пользователям предлагается бесплатный доступ, за доступ сверх лимита уже взимается плата. Кроме того, некоторые подписки включают доступ к Times Insider (набор эксклюзивного онлайн-контента и функций).

Искать пути снижения издержек газеты вынуждают и растущие типографские расходы, и отток читателей в Интернет. По этой причине в апреле 2008 г. компания The New York Times закрыла типографию в городе Эдисон, штат Нью-Джерси. В результате работу потеряли 1050 служащих, а компания обеспечила сокращение издержек на сумму в 42 млн долл. Как заявила в марте 2008 г. генеральный директор компании Джанет Робинсон, расширение присутствия газеты в Сети является «абсолютным приоритетом» компании (Бадмаева, 2009). The New York Times становится одним из ведущих поставщиков информации для крупнейших баз данных (Dow Jones Business Information Service) и электронных архивов (в частности, архив Университета штата Мичиган).

Несмотря на все сложности, связанные и с финансовым кризисом, и с новой цифровой реальностью, газета не изменяет главному кредо - это качество материалов и профессионализм сотрудников. Не случайно А. Окс Сульцбергер-мл. был уверен, что люди всегда будут нуждаться в качественной информации, которая определяет место The New York Times на медиарынке, и The New York Times будет существовать всегда.

\section{Артур Грег Сульцбергер (издатель и владелец The New York Times c 2018 r.)}

Один из основателей «цифровой трансформации» The New York Times, автор «Инновационного отчета 2014 года», в котором основное внимание уделялось привлечению цифровой аудитории The New York Times, возглавил газету в сложное время. «Мы распродали все подразделения, которые только смогли, чтобы свести расходы на журналистику к минимуму, - рассказывал А.Г. Сульцбергер в 2018 г. - Все светлые головы в СМИ сказали, что это безумие, а наши акционеры решили, что это безответственно с финансовой точки зрения» 5 .

Сегодня The New York Times ведет эксклюзивные переговоры о приобретении Serial 
Productions, передовой студии подкастов (более 300 млн скачиваний). Сделка потребует солидных капиталовложений: по мнению экспертов, стоимость Serial Productions оценивается в 75 млн долл., хотя ожидается, что The New York Times заплатит меньше (впервые о продаже компании сообщил The Wall Street Journal). В сочетании с популярным еженедельным подкастом газеты эта сделка может стать основой для нового амбициозного платного продукта вроде приложений с рецептами и кроссвордами. Руководители считают, что это будет некий аналог компании НВО, только в мире подкастов. По словам А.Г. Сульцбергера, The New York Times не столько доминирует на этом рынке, сколько создает его с нуля.

По состоянию на третий квартал 2019 г., в штате The New York Times 1600 журналистов, персонал говорит на 55 языках, у газеты 150 млн глобальных читателей ежемесячно. Общая выручка за третий квартал 2019 г. увеличилась на 2,7\% - до 428,5 млн долл. (417,3 млн долл. в третьем квартале 2018 г.). доходы от подписки увеличились на 3,7\% главным образом за счет роста в последние годы количества подписок на продукты только для цифровых устройств. (по данным comScore Media Metrix New York Times Digital, в октябре 2019 г. - 87 млн человек). На конец третьего квартала 2019 г. количество платных цифровых подписок составило приблизительно 4,05 млн, что на 31\% превышает показатели третьего квартала 2018 г. Выручка от цифровой рекламы в третьем квартале снизилась на 5,4\% - доход составил 54,7 млн долл., или $48,1 \%$ от общего дохода от рекламы компании (57,8 млн долл., или 47,5\%, в третьем квартале 2018 г.). Снижение доходов от цифровой рекламы в основном отражало снижение объема прямых продаж рекламы на основных цифровых платформах, что частично компенсировалось ростом числа подкастов. Выручка от рекламы в печатной версии в этот период снизилась на 7,9\%. Прочие доходы за этот же период выросли на 9,8 млн долл. (или на 25,9\%), в основном благодаря доходу, полученному от телесериала «Еженедельник»б.

The New York Times - уникальный образец семейного бизнеса в газетной индустрии, высокого профессионализма издателей и журналистов. Своими успехами газета обязана не только издателям, грамотно выстраивающим редакционную политику и своевременно реагирующим на все вызовы, но и журналистам. Работать журналистом в The New York Times очень престижно, это эталон, синоним профессионализма. Требования к корреспонденту очень высокие, и они практически не изменились со времен А. Окса.

\section{Заключение}

За свою 168-летнюю историю The New York Times приобрела репутацию одной из самых респектабельных и влиятельных газет в Соединенных Штатах Америки. Основанная в 1851 г. Генри Раймондом, газета вначале была только региональным изданием. При новом владельце, Адольфе Оксе, газета увеличивает свой тираж, постепенно расширяя географию распространения. Окс не только вывел газету на новый уровень, но и создал целую семейную империю.

Главный вклад в развитие The New York Times внесли ее владельцы и издатели. А.Х. Суцельберг усилил официальную направленность газеты. С развитием новых информационных технологий, ростом денежных доходов от рекламы The New York Times смогла выйти за пределы не только определенного округа, но и штата. В 1945 г. впервые удалось передать выпуск газеты в Сан-Франциско с помощью факсимильной печати.

Финансовый кризис 1960 гг. повлиял на прессу - в этот период The New York Times стала публиковать больше статей о частной жизни людей, развлекательных материалов. Появились новые рубрики, 
посвященные науке, изобразительному искусству, автомобилям, спорту, компьютерам, кулинарии. Газета предоставляла читателям ежедневную хронику событий и разнообразную тематику статей, совмещая "жесткие» и "мягкие» новости. Объем газеты значительно увеличился благодаря дополнительным рекламным вкладышам. Публикации серии статей о войне во Вьетнаме изменили саму журналистику Соединенных Штатов Америки, прессу стали расценивать как четвертую власть. В 1980 гг. The New York Times окончательно завоевала статус общенационального издания. А в 1990 гг. под влиянием нового поколения читателей газета упростила свой официальный стиль, уделив больше внимания скандальным статьям и криминальной хронике. А. Окс Сульцбергер-мл. изменил направленность элитарной The New York Times, адресовав ее не только богатым людям, высшему обществу, но и представителям разных социальных групп.

Однако для The New York Times важно не только (и не столько) представить информацию в наиболее привлекательном виде, сколько сохранить свою репутацию респектабельного издания, газеты, способной изменить взгляды людей, общество и, возможно, картину мира.

\section{Примечания}

${ }^{1}$ C 10 февраля 1897 г. по настоящее время слоган размещается на первой полосе каждого номера рядом с названием газеты. На сайте The New York Times девиз звучит несколько иначе: All the News That's Fit to... Click («Bсе новости, достойные... просмотра»).

2 Lipman W., Merz Ch. The Test of News. An Examination of the News Report in the New York Times on Aspects of Russian Revolution of Special Importance to Americans. 1920, March.

3 Гаков В. Время нью-йоркское // Коммерсантъ Деньги. 2001. № 36. С. 63.

4 The New York Times сокращает зарплату сотрудникам и готовится уволить 100 человек // Newsru.com. 2017. Дек., 7. Режим доступа: https://www.newsru.com/ finance/27mar2009/nytimes.html

5 Смит Б. Почему успехи «Нью-Йорк Таймс» не предвещают журналистике ничего хорошего. 2020. Март, 3. Режим доступа: https://gipp.ru/overview/mneniyaekspertov/the-new-york-times-ssha-pochemu-uspekhi-nyu-york-tayms-nepredveshchayut-zhurnalistike-nichego-khoro/

${ }^{6}$ The New York Times Company Reports 2019 Third-Quarter Results. 2019. June, 11. Peжим доступа: https://investors.nytco.com/press/press-releases/press-release-details/ 2019/The-New-York-Times-Company-Reports-2019-Third-Quarter-Results/default.aspx

\section{Библиография}

Акопов А.И. Периодические издания. Ростов н/Д: Книга, 1999.

Андрунас Е.Ч. Информационная элита: корпорации и рынок новостей. М.: Изд-во Моск. ун-та, 1991.

Ахмадулин Е.В. Пресса политических партий России начала XX века. Издания консерваторов. Ростов н/Д: Книга, 2001.

Бадмаева Н.И. Функционирование качественной газеты «Нью-Йорк Таймс»: конец XX - начало XXI вв.: дис. ... канд. филол. наук. М., 2009. 
Беспалова А.Г., Корнилов Е.А., Короченский А.П., Лучинский Ю.В. и др. История мировой журналистики. М.; Ростов н/Д: ИЦ «МарТ», 2003.

Вартанова Е.Л. Газета и ЭВМ. Некоторые аспекты взаимоотношения между современной компьютерной техникой и буржуазной печатью // Вестн. Моск. ун-та. Сер. 10: Журналистика. 1988. № 2. С. 74-84.

Вартанова Е.Л. Медиаэкономика зарубежных стран. М.: Аспект Пресс, 2003.

Голованова Г.А. Печать США в начале 90-х гг. М.: Фак. журн. МГУ, 1996.

Калягин Б.А. Характерные черты современной прессы США // Вестн. Моск. ун-та. Сер. 10: Журналистика. 2012. № 3. С. 116-131.

Качественная пресса в медийных структурах / под ред. Я.Н. Засурского. М.: Фак. журн. МГУ, 2015.

Кондратенко В.М. Эволюция редакционной политики газеты «Нью-Йорк Таймс» в освещении курса США во Вьетнаме, на Ближнем Востоке и в отношении разрядки международной напряженности (1964-1976): дис. ... канд. филол. наук. М., 1979.

Кугель В.Р. Очерки издательского и полиграфского дела. М.-Л.: Огиз. Гос. соц.экон. изд-во, 1931.

Макеенко М.И. Ежедневная печать: американский опыт конца XX столетия. 19952000 гг. М.: Изд-во Моск. ун-та, 2003.

Маркина Ю.В. Газета The New York Times: эволюция типа издания: дис. ... канд. филол. наук. Ростов н/Д, 2004.

Михайлов А.С. Журналистика Соединенных Штатов Америки. СПб.: Изд-во Михайлова В.А., 2004.

Прутцков Г.В. История зарубежной журналистики: 1800-1929. М.: Аспект Пресс, 2010.

Рогозина И.В. Трансформация устного политического текста в американской газете как метод пропагандистского воздействия (на материале газеты «Нью-Йорк Таймс», 1980-1986): автореф. дис. ... канд. филол. наук. М., 1988.

Berger M. (1952) The Story of New York Times. 1851-1951. N.Y.: Simon and Schuster. Catledge T. (1971) My Life and the Times. N.Y.: Harper \& Row.

Diamond E. (1994) Behind the Times. Inside the New York Times. N.Y.: Villard Books.

Emery M. (1988) The Press and America: an Interpretative History of Mass Media. N.Y.: Englewood Cliffs; N.J.: Prentice-Hall.

Salisbury H.E. (1980) Without Fear or Favor: The New York Times a. its times. N.Y.: Times books, Cop.

Schiller D. (1981) Objectivity and the News: The Public and the Rise of Commercial Journalism. Philadelphia: University of Pennsylvania Press.

Schudson M. (1978) Discovering the News: A Social History of American Newspapers. N.Y.: Basic Books.

Shepard R.F. (1996) The Paper's Papers: A Reporter's Journey Through the Archives of the New York Times. N.Y.: Times Books.

Sinclair U. (1921) The Crimes of the "Times». A Test of Newspaper Decency. Pasadena: Calif. Sulzberger I.O. (1971) Iphigene. N.Y.: Dodd, Mead\&Company.

Talese G. T. (969) The Kingdom and the Power. N.Y.: Bantam books. 